\title{
DIALÉTICA POSITIVA: DE MEAD A HABERMAS
}

FERNANDO HADDAD

\section{MEAD, POR HABERMAS}

Segundo Habermas, o interesse sobre a obra de G. H. Mead cresce na medida em que ela representa um ponto de intersecção das duas tradições de crítica à filosofia da consciência que têm uma origem comum no pragmatismo de Charles Sanders Peirce: a filosofia analítica da linguagem, de um lado, e a teoria psicológica do comportamento, de outro. Com efeito, Mead chama sua teoria de "behaviorismo social", marcando posição, desde logo, contra a filosofia da consciência e, ao mesmo tempo, rompendo com as premissas metodológicas e o objetivismo das teorias do comportamento. Mead abandona o individualismo metodológico, pois parte do "todo social" para, só dessa perspectiva, analisar a conduta dos elementos que o compõem; abandona também o objetivismo, pois leva em conta a experiência interna do indivíduo no conjunto do processo social, experiência essa objetivada nas expressões simbólicas. Dessa forma, Mead reúne aqueles dois ataques à filosofia da consciência que, depois de Peirce, mantiveram-se distantes.

A intersecção das duas vertentes do pensamento moderno aparece na obra de Mead tão logo esse autor se propõe a analisar o surgimento da interação simbolicamente mediada (linguagem especificamente humana) a partir da interação mediada por gestos (comum a outros vertebrados). Mead parte da linguagem por gestos por considerá-la a precursora do processo de semantização que caracteriza a linguagem por sinais. Mead ilustra a distinção entre essas diferentes formas de linguagem a partir de um exemplo tão simples como o de uma briga de cães. Assim que um cão percebe a atitude hostil de um outro da sua espécie, reage a essa ação. O primeiro cão, por sua vez, muda de atitude assim que percebe a reação 
do segundo cão a sua ação original. Há uma conversação de gestos entre os dois. Mead vê nessa conversação uma relação triádica - do gesto com o primeiro organismo, do gesto com o segundo organismo e do gesto com as fases subseqüentes do ato social em questão -que abre espaço para um campo de significado. Os movimentos iniciais do primeiro organismo constituem, para o segundo, uma indicação do resultado pretendido, tanto que esse segundo organismo reage àqueles movimentos iniciais antes mesmo que se dê o movimento completo, tomando-os como a intenção de produzir os resultados supostos. O primeiro organismo reage igualmente aos movimentos iniciais da reação do segundo. Dessa forma, pode-se dizer que ambos entendem os gestos um do outro, atribuindo-lhes um significado típico, mas que, até então, só vale para cada qual.

Para que a interação mediada por gestos se converta em uma interação mediada por símbolos, os significados a eles atribuídos, que inicialmente só valem para cada um dos organismos, têm que ser substituídos por significados que sejam idênticos para os dois participantes. Surgem os significant gestures, ou seja, aqueles "símbolos simples, não articulados sintaticamente, que em contextos iguais (ou suficientemente parecidos) têm um mesmo significado para ao menos dois participantes na interação" (Habermas, 1985: 13). Como se vê, o processo de transformação de gestos em símbolos já supõe um certo potencial semântico dos primeiros que, uma vez internalizados, convertem-se em símbolos utilizáveis pelos participantes na interação. Tanto quanto Piaget e Freud, que concebem o mecanismo de aprendizagem, respectivamente, como interiorização de mecanismos de ação e como internalização das relações com uma pessoa de referência, Mead concebe a internalização como subjetivação de estruturas objetivas de sentido, transladadas ao interior através de um mecanismo por ele denominado "taking the attitude of the other".

Habermas saúda mais essa iniciativa contra a idéia de uma relação reflexiva de um self que se relaciona consigo mesmo, convertendose em objeto de si. Adotar a atitude de outro significa, mais do que isso, reconhecer-se em algo externo, internalizando aquilo com o que se enfrenta como objeto. Dessa perspectiva, a relação de cada um consigo mesmo passa a ser vista como uma mera reprodução da relação entre participantes numa interação.

Sem dúvida, trata-se de um avanço. Habermas, contudo, sugere que o pensamento de Mead não vai suficientemente longe, pois que não compreende inteiramente que essa subjetividade, que não pode relacionarse consigo mesma senão mediatamente, supõe uma mudança na estrutura 
global da interação. Habermas tem em vista o fato de que, com o desenvolvimento da espécie, quanto mais complexas as atitudes do outro a serem internalizadas, mais os laços que unem os participantes na interação desprendem-se de regulações instintivas inatas para fixarem-se no plano da tradição cultural comunicativamente gerada. Não basta, portanto, segundo Habermas, explicar, por meio do mecanismo da adoção da atitude do outro, como surge a interação simbolicamente mediada. Tem-se que explicar, adicionalmente, $a$ ) como os participantes adotam os papéis de falante e destinatário e $b$ ) como as ações se diferenciam em ações comunicativas e ações não-comunicativas.

a) Mead explica a gênese de significados idênticos exclusivamente a partir da internalização decorrente da adoção, por um organismo, da atitude com que um outro reage a seus gestos. Nessas bases, preocupase unicamente com o início do processo de internalização das estruturas de sentido. Adotando um enfoque darwinista, Mead esposa a tese de que a pressão a adaptar-se que os organismos exercem uns sobre outros acaba premiando aqueles que não só interpretam os gestos do outro, mas também entendem o significado de seus próprios gestos à luz das reações esperadas. Daí privilegiar os gestos acústicos que, como nenhum outro, são tão bem percebidos pelo receptor quanto pelo emissor.

Habermas considera tal explicação insuficiente. Se um gesto desperta uma reação idêntica tanto no receptor quanto no emissor, tudo o que se pode dizer é que houve uma interpretação coincidente do gesto em questão, mas não se pode ainda afirmar que haja necessariamente um significado idêntico para ambos. "Que ambos interpretem o mesmo estímulo de forma coincidente é um estado de coisas que é em si, mas que não existe para eles". Faz-se mister que o organismo receptor apareça ao organismo emissor não apenas como um ente que reage adaptativamente aos seus estímulos, mas como um objeto social que, com sua reação, dá expressão a uma interpretação dos gestos desse último. O emissor relaciona-se com o receptor como um destinatário que interpreta de uma determinada forma o gesto que se lhe faz com intenção comunicativa; quer dizer, ambos "comportam-se entre si como um ego que dá algo a entender a um alter ego". Tomar a atitude do outro, portanto, não se resume simplesmente a antecipar sua reação a um gesto, mas igualmente tomar esse outro como um intérprete desse gesto.

b) Se isso é assim, há outro aspecto a considerar. Pois que, nessas condições, os participantes podem distinguir entre atos comunicativos 
que um ego dirige a um alter, e ações orientadas ao êxito que visam tão somente causar algo. Cria-se a possibilidade de que ego, diante de uma reação inesperada de alter, manifeste sua decepção, não somente em relação às conseqüências indesejadas dessa reação, mas também em relação à própria comunicação frustrada. Mas se os participantes podem adotar uma postura crítica frente à interpretação falida de um ato comunicativo, ao fazê-lo, não estarão empenhados em outra coisa que não o desenvolvimento de regras de uso dos símbolos, condição sem a qual não se formam "convenções semânticas e símbolos utilizáveis com significado idêntico".

Diante dessas lacunas da teoria meadiana, Habermas decide recorrer ao conceito de regra, tal como entendido por Wittgenstein, para, por um lado, $c$ ) esclarecer a conexão entre identidade de significado e validez intersubjetiva e, por outro, $d$ ) dar uma forma mais rigorosa à gênese lógica das convenções semânticas.

c) Segundo Habermas, os significados simbólicos constituem identidade de maneira similar a como fazem as regras. "Entende-se o significado de uma determinada ação simbólica, por exemplo, de uma jogada de xadrez, quando se domina a regra conforme a qual há que se mover as correspondentes figuras. A compreensão de uma ação simbólica está ligada à capacidade de seguir uma regra" (idem: 29). Sem uma regulação convencional não há identidade de significados. Isto quer dizer, por exemplo, que a avaliação da conduta de alguém em relação a uma regra qualquer não pode reduzir-se à simples observação de regularidades empíricas, já que a violação a uma regra só pode ser atestada se ela for conhecida pelo ator e seu crítico. A identidade de uma regra, portanto, depende de sua validez intersubjetiva tanto quanto a identidade de significados. Ninguém que simplesmente crê seguir uma regra a segue necessariamente, a menos que seu comportamento seja suscetível de julgamento por outrem. Sendo assim, "para que um sujeito possa seguir uma regra (...), esta há que reagir intersubjetivamente ao menos para dois sujeitos. [Segundo Habermas], com a análise do conceito de 'seguir uma regra', Wittgenstein demonstra que a identidade de significados se remonta à capacidade de seguir regras intersubjetivamente válidas junto com, ao menos, mais outro sujeito; ambos têm que dispor da competência de ajustar seu comportamento a regras, assim como de ajuizar criticamente tal comportamento. Um sujeito isolado e solitário, que só dispusesse de uma dessas duas competências, não poderia nem formar uma regra, nem empregar símbolos com identidade de significados" (idem: 31s). 
d) Na segunda dessas competências, ajuizar criticamente um comportamento, Habermas encontra um elemento fundamental para elucidar a gênese lógica das convenções semânticas. No nível pré-simbólico, uma emissão qualquer - um pedido de ajuda, por exemplo -, pode não produzir o efeito previsto pelo emissor. Nesse nível de interação ainda não se pode falar de comportamento incorreto, seja do emissor, seja dos receptores, já que todos se encontram numa situação de ausência de convenção que fixe a identidade do significado. Habermas pergunta-se pelo elemento novo que permite que, no nível simbólico de interação, possa-se falar de uma consciência de regra das partes envolvidas.

Evidentemente, os receptores de um pedido de ajuda podem não agir segundo a expectativa do emissor, ou por causas triviais (encontravamse imobilizados, por exemplo), ou por não terem interpretado a emissão no sentido esperado. Outro é o caso, porém, em que os receptores negam-se a atender o pedido porque o emissor equivocou-se sobre as circunstâncias em que aquela emissão é geralmente entendida como uma petição de auxílio (como quando o emissor confunde gestos de saudação com gestos de ataque). Nesse caso, diferentemente, os receptores tomam uma postura, com um "sim" ou um "não", frente à pretensão do emissor.

Quando os membros de uma comunidade internalizam as reações de recusa de seus pares as suas pretensões, "aprendem a dirigir-se mutuamente vozes antecipando posturas críticas para os casos em que uma emissão não se empregue de forma adequada ao contexto". Essas antecipações críticas criam, por sua vez, as condições para o estabelecimento de convenções semânticas que vêm fixar o emprego dos símbolos. Assim, segundo Habermas, a competência de seguir uma regra e a capacidade de tomar uma postura crítica em relação ao uso que se faz de um símbolo (diante da regra que rege seu emprego), são competências co-originárias e determinantes para a aquisição de uma consciência de regra que fixe convencionalmente o significado desse símbolo.

Feitas essas considerações, torna-se mais satisfatória a explicação da transformação, que marcaria o umbral da hominização, da interação mediada por gestos em interação mediada por símbolos. Habermas, contudo, não se dá por satisfeito. Isto porque a teoria de Mead, segundo ele, mesmo com os complementos wittgensteinianos propostos, não esclarece de forma definitiva "como um sistema diferenciado de linguagem pode substituir os anteriores reguladores do comportamento inatos de cada espécie". Habermas acusa Mead de passar diretamente da ação mediada simbolicamente à ação regulada por normas, sem se dar conta de que a 
primeira não requer nem uma organização sintática desenvolvida nem uma convencionalização completa dos signos, a ponto de penetrar as bases motivacionais e o repertório comportamental dos participantes, cujas ações, sem um sistema de linguagem diferenciada proposicionalmente, são coordenadas por um tipo de regulação ainda baseada em resíduos instintuais.

Habermas, então, $e$ ) introduz mais um estágio na teoria meadiana da evolução da linguagem, a da linguagem diferenciada; $f$ ) rediscute, à luz desta reformulação, o processo de constituição dos mundos objetivo, social e subjetivo e, finalmente $g$ ) reprova, em Mead, a ausência de um tratamento filogenético para descrever tanto o processo de interação social como o processo de socialização que lhe é complementar.

e) Para ilustrar as diferenças entre linguagem por sinais e linguagem diferenciada, Habermas toma o mesmo exemplo de um pedido de ajuda que um emissor faz a seus ouvintes, com dois ingredientes adicionais: os participantes dispõem agora de uma linguagem proposicionalmente diferenciada e, além disso, há uma diferença de status social entre o emissor e seus possíveis receptores (a favor do primeiro). Nesse caso, os ouvintes entendem a emissão alternativamente como uma constatação (da presença de inimigos), como um mandato (que o emissor faz a seus interlocutores para prestar-lhe auxílio) e como uma expressão (do temor do emissor frente ao perigo da situação). Nessas circunstâncias, como "emitem orações de vivência ou orações de tipo normativo, (...) os participantes na comunicação têm que se referir a algo em um mundo subjetivo ou em um mundo social comum, da mesma forma que com os atos de fala constatativos fazem referência a algo em um mundo objetivo. De modo que, só quando se hão constituído esses mundos, ou ao menos quando, incoativamente, se hão diferenciado, funciona a linguagem como meio de coordenação" (idem: 43). Pois nesse novo contexto, os ouvintes podem agora questionar uma emissão, pondo em dúvida sua verdade, sua legitimidade e sua veracidade. Com a crítica tornada possível, passa-se de um modo de controle da interação de tipo pré-linguístico e instintual, embora simbólico, a um modo dependente da linguagem e ligado a uma tradição cultural. ${ }^{1}$

1 Dessa forma, a saída teórico-comunicativa de Habermas implica, em primeiro lugar, uma valorização daquelas estruturas do mundo que se estendem para lá da existência isolada, antes depreciadas por Heidegger como estruturas de uma existência inautêntica. Nesta operação de valorização do mundo consiste o giro materialista de Habermas. Habermas quer explicar "de que modo o mundo da vida, ele próprio desprovido de sujeito, mesmo assim se reproduz através dos sujeitos e do seu agir orientado para o entendimento mútuo". É dessa forma que ele pretende responder à questão do "quem" da existência, que Heidegger reduz "a um sujeito 
f) Habermas observa que a constituição desses três mundos, o mundo objetivo, o mundo social e o mundo subjetivo, não recebe, na obra de Mead, um tratamento equilibrado. A diferenciação de um mundo objetivo de coisas, por exemplo, só é tratado de forma superficial, mas mesmo nesse particular Habermas não deixa de lhe reconhecer os méritos. Quanto a isso, ainda que Mead não tenha atentado para a estrutura proposicional da linguagem, ao menos ele analisa, do ponto de vista da psicologia da percepção, a estrutura cognitiva que subjaz a formação de proposições. No mundo das espécies inferiores, segundo Mead, não há um mundo perceptivo de coisas físicas, mas tão somente um mundo de estímulos e reações conducentes a um fim, onde a ação precede o ato de presença das coisas. No mundo da criança, contrariamente, já há um mundo físico perceptivo. Mead vai insistir no caráter originariamente social dessa percepção, defendendo a tese de uma "progressiva dessocialização das relações com os objetos físicos".

"A criança - ensina Mead - encontra suas soluções do que do nosso ponto de vista são problemas inteiramente físicos, tais como transporte, movimento de coisas, etc, através da sua reação social àqueles próximos a ela. Isto não é simplesmente porque ela é dependente, e deve olhar para aqueles que lhe são próximos para assistência durante o período da primeira infância, mas, mais importante ainda, porque seu processo primitivo de reflexão é aquele de mediação por gestos vocais de um processo social cooperativo. $O$ indivíduo humano pensa antes de tudo em termos inteiramente sociais" (Mead, 1950: 377; grifos meus - FH).

Apesar das virtudes dessa concepção, o que, segundo Habermas, Mead não percebe é que o processo de dessocialização das relações com os objetos físicos, que ao final constitui um mundo objetivo totalmente diferenciado, não pode amparar-se num mecanismo de coordenação de ações por meio de sinais, mas exige uma linguagem proposicionalmente diferenciada. Os sinais só mantêm sua capacidade de coordenar ações, baseada, em última instância, em regulações instintivas, enquanto os componentes

que constitui o mundo do ser-no-mundo através do projeto das suas possibilidades de existência" (Habermas, 1990: 146). Habermas encontra no agir comunicativo dos participantes numa interação mediada lingüisticamente a única maneira de escapar daquela atitude objetivante que um sujeito isolado assume em relação ao mundo. O mundo da vida, em Habermas, continua sendo, como em Heidegger, aquele horizonte pré-temático no qual os existentes se movimentam desde sempre e no qual vão buscar os seus padrões de interpretação do que se encontra à mão. Contudo, o mundo da vida é visto agora como o pano de fundo aproblemático no qual falantes e ouvintes se entendem sobre algo no mundo. 
descritivos, imperativos e expressivos permanecem fundidos. Só “com o modo assertório de uso da linguagem, os atos comunicativos cobram, pois, a força de coordenar as ações através de um acordo motivado racionalmente" (Habermas, 1985: 48).

Quanto à constituição do mundo social, a abordagem de Mead é mais complexa: ela se dá por etapas. Mead parte de uma situação social assimétrica representada pela relação entre pai (ou outra pessoa de referência) e filho. Numa primeira etapa, o filho cumpre os imperativos do pai, observando o plexo de sanções e prêmios a eles vinculado; além disso, observa também o contexto mais geral no qual vê satisfeitas pela pessoa de referência suas próprias necessidades. Nessa etapa, o filho percebe sua relação com o pai como uma satisfação mútua de interesses: quando cumpre um imperativo não faz outra coisa senão satisfazer um interesse do pai que, reciprocamente, satisfaz um interesse seu. Evidentemente, essa conexão que, aos olhos do pai, é o resultado de normas que regulam a relação genérica pai-filho, para o filho significa tão somente o resultado de expectativas particularistas de comportamento referidas uma à outra. Mas, ainda assim, Mead destaca dois importantes elementos dessa conexão: 1) a compreensão dos plexos de sanções e prêmios exige do filho a capacidade de referir-se ao menos elementalmente a um mundo de objetos perceptíveis, e 2) a complementaridade de ações que têm como consequiência a satisfação mútua de interesses é apreendida pelo filho, adotando a atitude do outro, ou seja, antecipando que a atenção do pai a seus apelos envolve a expectativa de que ele cumpra os imperativos a ele endereçados.

Para Mead, tanto quanto para Freud, esses padrões de comportamento se desligam das intenções das pessoas particulares e da vinculação de tais intenções a um determinado contexto, e adquirem a forma externa de normas sociais à medida que as sanções associadas com elas são internalizadas mediante a adoção da atitude do outro. Nessas circunstâncias, quando cumpre um imperativo, o filho se vê atendendo a uma espécie de arbítrio suprapessoal ao qual tanto ele quanto seu pai estão submetidos. Esse processo de formação dessa vontade suprapessoal, Mead a observa nos jogos nos quais a criança se dedica a mudar de papel (play), ora atuando como bandido, ora como mocinho, ora como vendedor e, imediatamente depois, como comprador etc.

Num jogo de papéis, porém, a criança adota padrões concretos de comportamento, válidos exclusivamente nas situações em que somente ela e uma pessoa de referência se relacionam. Sua capacidade de generalização envolve as dimensões do espaço e do tempo, mas ela ainda não é 
capaz de perceber que quaisquer outros dois membros da sua comunidade podem adotar igualmente aqueles papéis; quer dizer, ela não é capaz de perceber que aqueles papéis são, na verdade, papéis sociais.

Mas, como vimos, no estágio em que a criança entende uma exigência, ela já deve estar apta a adotar uma atitude objetivante frente às coisas, para poder compreender o complexo de rendimentos positivos e negativos que envolve tal mandamento. Se, portanto, a criança estender essa atitude objetivante não somente às coisas, mas à própria interação que estabelece com outrem, ela poderá vir a distinguir o papel comunicativo de qualquer participante de uma interação da seguinte forma: em um papel de um alter ego e em um papel de um neuter ñ ou seja, de um mero espectador, um terceiro não implicado. E ao fazê-lo, tornar-se-á consciente da intercambialidade das posições que ocupava na relação com o outro. Agora, a criança "se dá conta de que o que para ela parecia um padrão concreto de comportamento, recortado à medida desta criança e destes pais, havia sido desde sempre para [o outro] uma norma que regulava com caráter geral a relação entre filhos e pais. Com esta adoção da atitude de neuter, [a criança] forma o conceito de um padrão de comportamento socialmente generalizado, quer dizer, estendido a todos os membros do grupo, padrão cujas posições não estão reservadas exclusivamente a ego e alter, senão que em princípio podem ser ocupadas por todos os membros de seu grupo social" (idem: 57).

Cumpre notar, entretanto, que nesse estágio a assimetria da relação entre filho e pai não foi ainda totalmente superada, pois que o primeiro, por enquanto, somente está apto a considerar as normas de ação como um arbítrio generalizado de todos os membros do grupo. Violá-las significa agora vulnerar o interesse de todo o grupo, e não somente o do interlocutor direto. Os filhos devem se comportar dessa ou daquela forma e quem quer que esteja na condição de filho deve se comportar assim em relação ao pai: o filho entende assim a regra, que não deixa de ser, não obstante a forma geral, tão arbitrária quanto quando ela era entendida como um imperativo de uma pessoa particular de referência. Mas, aqui, já não se trata de um jogo de papéis (play), mas um jogo competitivo (game) no qual o indivíduo tem que considerar as atitudes de todos os outros que nele intervêm, pelo menos na medida em que elas afetam sua resposta particular.

A assimetria da relação entre o indivíduo e a pessoa de referência só é inteiramente superada com o conceito de validez normativa. Isso acontece quando a autoridade do grupo que, a princípio, reveste a forma de simples imperativos, transforma-se em autoridade normativa por meio de 
internalização, isto é, quando o indivíduo "considera as sanções do grupo como suas próprias, como sanções dirigidas por ele contra ele mesmo, tendo que pressupor seu assentimento à norma cuja violação censura dessa forma" (idem: 60). Correlativamente, quando o indivíduo internaliza a autoridade, torna-se capaz de afirmar seus direitos, provocando respostas dos outros membros da comunidade a que pertence, respostas essas que ele próprio daria se estivesse em situação análoga. Às séries de tais respostas comuns na comunidade em que vivemos chamamos instituições: "À diferença dos imperativos socialmente generalizados, as instituições possuem uma validez que provém do reconhecimento intersubjetivo, do assentimento dos afetados" (idem: 60).

Este é o momento de elucidar a questão de como se efetua a constituição de um mundo subjetivo, complementar ao mundo social. Pois quando o indivíduo adquire a competência de participar de interações normativamente reguladas, ele também se torna capaz de adotar uma atitude objetivante em relação às instituições, o que significa a possibilidade de encará-las como mais um elemento não-normativo de uma dada situação de ação. Esta competência permite ao indivíduo reordenar simbolicamente suas próprias disposições comportamentais o que, do ponto de vista da socialização, apresenta-se como formação de uma identidade. Mead trata a questão sob o aspecto de uma relação entre o $M e$ e o $I$. "Me, para Mead, é o conjunto organizado de atitudes de outros que alguém assume por si mesmo. As atitudes de outros constituem o Me organizado". "O I é a resposta do organismo à atitude de outros" (Mead, 1950: 175). Numa dada situação, o indivíduo dispõe, em si mesmo, daquelas séries de atitudes dos outros constituintes do $\mathrm{Me}$ que clamam por uma certa resposta, resposta esta que, não obstante, sendo dada pelo $I$, é mais ou menos incerta. "Há uma necessidade moral, mas não uma necessidade mecânica para o ato", ensina Mead: "o I dá o senso de liberdade, de iniciativa". Sem ele não haveria nada novo. O $I$, assim, é uma espécie de subjetividade que se ergue sobre o transfundo de um superego. A dinâmica de $I$ e $M e$ explica como o indivíduo estabelece, paulatinamente, limites cada vez mais precisos, entre um mundo externo condensado em instituições e um mundo interno de vivências espontâneas.

"Mead [portanto] concebe a identidade pessoal... como uma estrutura que nasce da adoção de expectativas de comportamento socialmente generalizadas: o Me é o conjunto organizado de atitudes que se adotam das pessoas de referência. Mas, (...) Mead parte do fato de que a formação da identidade tem lugar através do meio de comunicação lingüísti- 
ca; e como a subjetividade das intenções, desejos e sentimentos do indivíduo não pode subtrair-se de modo algum a esse meio, as instâncias do $I \mathrm{e}$ do $M e$, do eu e do superego, têm que dimanar do mesmo processo de socialização. Mead adota a este respeito uma convincente posição (...) : o processo de socialização é ao mesmo tempo um processo de individuação" (Habermas, 1985: 87).

Com essa formulação, por assim dizer, dialética - dialética positiva, bem entendido, que não abre espaço para o enfrentamento do tema da dominação entre homem e natureza e dos homens entre si -, Mead, segundo Habermas, escapa definitivamente das malhas da filosofia da consciência. Explica a relação entre identidade do grupo e identidade dos membros que o compõe por meio de uma estrutura de perspectivas dada pelos distintos papéis comunicativos que se pode assumir. O I que toma posturas, a princípio imprevisíveis, com um "sim" ou com um "não", diante das ofertas que se lhe apresentam, é um elemento tão essencial para a constituição do Self quanto o $M e$ : não se pode renunciar ao espaço de liberdade e espontaneidade que ele representa. No processo de socialização, as pessoas, por um lado, aprendem a agir autonomamente dentro de um marco de referência universalista para, por outro lado, desenvolver-se em sua subjetividade e particularidade: o processo envolve tanto a autodeterminação de um agente que pode até mesmo enfrentar todos os seus contemporâneos, invocando vozes de uma comunidade mais ampla que inclui o passado e o futuro, quanto a auto-realização de um agente que afirma seu valor próprio através de atividades criadoras, incluindo-se aí as do artista e as do cientista.

A descrição do processo de constituição dos três mundos torna claro o motivo que leva Habermas a enfatizar a distinção entre a linguagem como meio em que tem lugar o entendimento, e a linguagem como meio em que têm lugar a integração social e a socialização dos indivíduos. Certamente, tanto a integração social quanto a socialização dos indivíduos dão-se mediante atos de entendimento, "mas à diferença do que acontece com os processos de entendimento, não se sedimentam em saber cultural, senão em estruturas simbólicas do si mesmo (Self) e da sociedade [instituições - FH]" (Habermas, 1985: 40). ${ }^{2}$

2 Habermas, como se vê, não só abandona o solipsismo da filosofia de Heidegger para redefinir o conceito de mundo, como também o submete, baseando-se na teoria de Austin dos atos de fala, a um alargamento. Essa é a segunda implicação da saída por ele proposta: um giro pragmático. Habermas vai buscar, na linguagem utilizada na comunicação entre os participantes, a referência para desvendar as estruturas desse mundo da vida partilhado intersubjetivamente. A partir da análise dos casos puros dos atos de fala - constatativos, regulativos e 
g) Finalmente, sobre a complementaridade do processo de integração e socialização, Mead afirma que "se o indivíduo atinge seu self somente por meio de comunicação com outros, somente através de elaboração do processo social por meio de comunicação significante, então o self não poderia anteceder o organismo social: o último teria que estar lá primeiro" (Mead, 1950: 233). ${ }^{3}$

\section{O MATERIALISMO PRAGMÁTICO DE HABERMAS}

Para compreender o impacto do pragmatismo meadiano sobre o materialismo histórico habermasiano, convém sublinhar as suas conseqüências no plano normativo. Isto porque Habermas, como veremos, quer reconstruir o materialismo histórico não só do ponto de vista cognitivo-instrumental, como, na sua opinião, teria feito Marx, como também do ponto de vista prático-moral. E o próprio Habermas reconhece a "colocação privilegiada que atribui às estruturas normativas no âmbito da evolução social" (Habermas, 1976: 35). Mas por que ele adota essa estratégia? Relembremos,

expressivos -, Habermas completa a caracterização desse contexto referencial por trás dos participantes na interação. "Os participantes já não vão buscar a este mundo da vida somente [como em Heidegger - FH] os padrões consensuais de interpretação (o saber de base do qual se alimentam os conteúdos proposicionais), mas também os padrões de relações sociais de confiança no plano normativo (as solidariedades tacitamente implícitas em que se apóiam os atos elocutórios) e as competências adquiridas no processo de socialização (o pano de fundo das intenções do locutor)" (Habermas, 1990: 291).

3 Segundo Habermas, esta afirmação indicava, ela própria, que havia uma outra importante tarefa teórica a desempenhar, a saber, explicar, do ponto de vista filogenético, a instância do "generalized other", sem a qual o processo de socialização não é possível. Mead ensaia essa solução na quarta parte do seu Mind, Self and Society, onde procura estabelecer as diferenças entre as sociedades humanas e as sociedades de insetos e vertebrados. Mas, ainda aqui, acaba por considerar somente o nível de socialização possibilitado pela comunicação através de símbolos, negligenciando o papel da linguagem proposicionalmente diferenciada. Além disso, descreve o aparecimento da linguagem por sinais, recorrendo, inexplicavelmente, a exemplos tomados da ontogênese, particularmente o dos jogos competitivos. "Mead procede circularmente - atesta Habermas -: para explicar o trânsito filogenético da interação mediada simbolicamente à interação mediada por normas, lança mão de uma instância que introduziu ontogeneticamente, ainda quando a ontogênese desse 'outro generalizado' não pode, por sua vez, explicar-se sem recorrer à filogênese" (Habermas, 1985: 67). As limitações da abordagem de Mead que têm a relação ontogênese/filogênese como pano de fundo ficam patentes sempre que se trata de considerar as raízes históricas de fenômenos como a fé religiosa, o patriotismo e o núcleo arcaico da moderna consciência normativa representado pelos símbolos sacros. Por isso, Habermas vai recorrer à teoria da religião de Durkheim, que não nos interessa aqui, para completar o programa reconstrutivo de Mead. 
num primeiro momento, como Marx descreve a crise de um modo de produção: "num determinado momento do seu desenvolvimento - diz Marx, nessa famosa passagem do prefácio à Contribuição à crítica da economia política -, as forças produtivas materiais da sociedade entram em contradição com as relações de produção existentes, ou seja, com as relações de propriedade (que são apenas sua expressão jurídica) no interior das quais tais forças haviam desenvolvido até esse momento. Essas relações, de forma de desenvolvimento das forças produtivas, convertem-se em entraves. E emerge assim uma época de revolução social". A isso Habermas acrescenta: a partir dessa descrição da crise "podemos entender a explicitação das forças produtivas como um mecanismo que cria problemas e que, decerto, abre caminho para a subversão das relações de produção e para a renovação evolutiva do modo de produção: mas que não as produz" (idem: 127). "Evidentemente - continua Habermas - permanece a questão do modo pelo qual essa passagem [de um modo de produção a outro] se realiza. A resposta descritiva do materialismo histórico diz: ela se realiza através de conflitos sociais, através da luta, através de movimentos sociais e choques políticos (...). Mas só uma resposta analítica pode explicar por que uma sociedade dá um passo evolutivo (...). A resposta que gostaria de propor soa assim: o gênero aprende não só na dimensão (decisiva para o desenvolvimento das forças produtivas) do saber tecnicamente valorizável, mas também na dimensão (determinante para as estruturas de interação) da consciência prático-moral. As regras do agir comunicativo desenvolvem-se, certamente, em reação a mudanças no âmbito do agir instrumental e estratégico; mas, ao fazê-lo, seguem uma lógica própria" (idem: 128; grifos meus - FH). Esta lógica própria do agir comunicativo é a lógica da ação orientada para o acordo, lógica que, segundo Habermas, pressupõe o alargamento teórico do conceito de razão para além da razão instrumental.

A recepção do pragmatismo por Habermas não se deu, contudo, sem mediação, a partir da leitura das obras dos seus principais representantes, de Peirce a Kohlberg. Essa recepção foi precedida pela decisiva influência da leitura de Karl-Otto Apel dos filósofos anglo-americanos, particularmente de Peirce. Nesse momento, referir-me-ei especificamente a um instigante ensaio de $A$ transformação da filosofia, intitulado "De Kant a Peirce" (1970). Nesse ensaio, são considerados os trabalhos de Peirce no âmbito da filosofia da ciência. Naquilo que é essencial para a defesa da tese de Apel, como se verá, as contribuições de Popper, Kuhn, Lakatos etc sobre o tema teriam pouco a acrescentar e, de fato, encontrariam implicitamente na obra de Peirce um pano de fundo comum. 
Segundo Apel, Peirce foi o primeiro a descrever, com propriedade, na série de papers intitulada Ilustrações da lógica da ciência, como se desenvolve o processo de produção da ciência moderna. Em How to make our ideas clear, segundo paper da série, Peirce sugere que seu método já havia sido intuído por Descartes, quando este distingue o conceito de idéia clara do conceito de idéia distinta. O primeiro conceito cartesiano estabelece que uma idéia clara é aquela que é apreendida de tal maneira que não pode ser tomada por qualquer outra. Como a experiência demonstrava que homens claros e positivos divergiam sobre princípios fundamentais, Descartes, segundo Peirce, teria concluído que esse conceito, por si só, não garantiria a validez do conhecimento, o que o fez estabelecer o conceito de idéia distinta, definida como aquela que não contém nada que não seja claro. Esse segundo conceito sugeria, segundo Peirce, que as idéias claras deveriam submeter-se ao teste de exame dialético, de tal maneira que ela só seria considerada uma idéia clara se a discussão a seu respeito não trouxesse à tona nenhum ponto obscuro com ela conectado. Se esta tivesse sido a interpretação dada à obra de Descartes, de um só golpe, se teria superado o "método da autoridade", entendido como aquele que vê na autoridade a última fonte de verdade, e o "método a priori" dos grandes pensadores, entendido como o que vê na autoconsciência a fonte do saber. Contudo, como a noção de distinção foi interpretada, graças a Leibniz, simplesmente como a apreensão clara de tudo o que está contido na definição, o cartesianismo representou meramente a passagem do método da autoridade ao método a priori. De qualquer forma, o próprio Peirce afirma que essas distinções deveriam ser relegadas ao relicário da Lógica, e será a partir de uma reconstrução crítica da Crítica da Razão Pura, de Kant, que ele procurará descrever seu próprio método.

Para tornar compreensível a validez objetiva da ciência (o que implica, por exemplo, poder afirmar que um corpo $\grave{E}$ pesado, e não, simplesmente, que, quando se o carrega, sente-se uma pressão de peso), Kant recorre ao que ele denomina "unidade da consciência" na "síntese transcendental da apercepção". "As múltiplas representações que são dadas numa certa intuição - ensina Kant - não seriam todas representações minhas se não pertencessem todas a uma autoconsciência, isto é, como representações minhas (...) precisam conformar-se à condição unicamente sob a qual podem reunir-se numa autoconsciência universal, pois do contrário não me pertenceriam sem exceção. Dessa ligação originária pode-se inferir muitas coisas. A saber, esta identidade completa de um múltiplo 
dado na intuição contém uma síntese de representações (...)". Assim, "a unidade sintética da consciência - continua ele - é, portanto, uma condição objetiva de todo conhecimento (...) pois sem essa síntese o múltiplo não se reuniria numa consciência". Esta unidade sintética - conclui Kant denomina-se unidade objetiva e distingue-se da subjetiva que "é uma determinação do sentido interno, mediante o qual aquele múltiplo da intuição é dado empiricamente (...)" (Kant, 1781: 81ss.).

O que faz Peirce, então? Segundo Apel, ao introduzir a dimensão pragmática na "lógica da ciência", ele substitui a unidade sintética da apercepção pela possibilidade de alcançar um acordo intersubjetivo entre as consciências através da interpretação dos signos. Neste sentido, Apel estabelece: "a dimensão pragmática representa na moderna 'logic of science' o análogo semiótico da 'síntese transcendental da apercepção' postulada por Kant. Do meu ponto de vista, da mesma forma que Kant, como analítico da consciência, se viu obrigado a postular, com anterioridade a toda crítica do conhecimento que é possível alcançar, algo semelhante à unidade do objeto (e da autoconsciência), os modernos lógicos da ciência, que partem de uma base semiótica ou análitico-linguística, teriam que postular a possibilidade de alcançar mediante a interpretação dos signos algo semelhante a uma interpretação do mundo, intersubjetivamente unitária” (Apel, 1985: 152). Mas isto implica que a lógica da ciência moderna pressupõe uma ética. $\mathrm{O}$ próprio Peirce teria percebido, segundo Apel, "que não poderia derivar a racionalização moralmente relevante da conduta humana a partir da normatização tecnológica para 'aclarar as idéias' no sentido da 'máxima pragmática', senão que, pelo contrário, teria que pressupô-la inclusive para fundamentar uma lógica normativa da ciência” (ibidem).

De qualquer forma, será alguém saído das hostes do pragmatismo, Lawrence Kohlberg, que, na esteira dos trabalhos de Piaget sobre o desenvolvimento cognitivo, proporá, ainda no plano ontogenético, a existência de estágios de desenvolvimento prático-moral - pré-convencional, convencional e pós-convencional -, abrindo espaço para que essa mesma abordagem pudesse ser extrapolada para o plano filogenético, o que é feito por Habermas a partir de uma releitura crítica das obras de Weber e Durkheim. Assim, não só os métodos da ciência descritos por Peirce são colocados em perspectiva histórica - tanto do ponto de vista do indivíduo quanto do ponto de vista social -, mas também seu próprio método pragmático pode ser visto como o ponto de culminância de um longo desenvolvimento que pressupõe a idéia de uma moral universalista pós-convencional que o fundamenta. 
Habermas, ainda nessa mesma linha de investigação, reconhece, não obstante, que é Mead o primeiro teórico a tentar fundamentar uma moral universalista como resultado de um desencantamento do potencial de racionalização contido na ação comunicativa. Essa nova fundamentação aparece em Mead na forma de uma crítica às morais universalistas precedentes, quais sejam, a utilitarista e a kantiana. Com elas, evidentemente, a teoria moral de Mead compartilha a idéia básica de que as normas morais fazem valer um interesse geral. Nisso, qualquer moral universalista tem que coincidir. Entretanto, assim como muita coisa distingue o utilitarismo da teoria moral kantiana, o mesmo pode ser dito sobre a moral meadiana com respeito ao utilitarismo e à teoria moral kantiana. Comecemos, pois, por realçar as diferenças que existem entre essas duas últimas.

A crítica de Kant ao utilitarismo pode ser resumida na distinção, cara ao primeiro, entre interesse e valor, ou inclinação e dever. Para Kant, o utilitarismo nada mais faz do que transformar o interesse em princípio ético, convertendo-o em um valor. Dessa coincidência entre interesse e valor, o utilitarismo deriva uma outra: a coincidência entre utilidade particular e utilidade pública, de resto implícita na conhecida fórmula "a máxima felicidade dividida pelo maior número de pessoas". A idéia de que, fazendo-se bem a si próprio, faz-se bem à sociedade (Bentham), ou de que fazendo bem à sociedade, faz-se bem a si mesmo (Comte), encontrava amparo, do ponto de vista utilitarista, na lei da associação psicológica (James Mill) ou no sentimento de unidade humana (John Stuart Mill). Evidentemente, a primeira fórmula, a de Bentham, será abraçada com entusiasmo, por motivos óbvios, por aqueles que serão os maiores nomes da economia política clássica (Smith, Ricardo, Malthus etc); enquanto a segunda, a de Comte, abrirá espaço para a fundamentação de uma nova disciplina: a sociologia.

O que os críticos do utilitarismo procuraram demonstrar é que a mera possibilidade de generalização de interesses particulares não garante a existência de um interesse dotado da autoridade de um interesse geral, passível de reconhecimento pelos afetados como um interesse comum. "O utilitarismo não explica o momento de assentimento reflexivo, racionalmente motivado, que as normas válidas exigem de todos os afetados" (Habermas, 1985: 133). É precisamente isso que Kant tem em vista quando introduz o imperativo categórico como princípio de legislação que todas as normas morais hão de satisfazer. "Com sua ajuda cada indivíduo pode julgar se uma norma dada ou recomendada merece assentimento geral" (idem, 134): para tanto, basta verificar se ela responde à exigência de uni- 
versalização. Uma norma que não possa se universalizar não corresponde a nenhum interesse que tenha caráter geral.

Mead simpatiza com o formalismo dessa solução, mas, como todos os críticos de Kant, observa sua insuficiência. Uma norma há que poder adotar a forma de um dever universal, mas isso não é um impeditivo para que se formule, dessa mesma forma universal, máximas imorais ou carentes de conteúdo moral. ${ }^{4}$ Mead procura contornar o problema com a seguinte consideração: "nós somos o que somos pelo nosso relacionamento com outros. Inevitavelmente, então, nosso fim deve ser um fim social, ambos, de um ponto de vista do seu conteúdo, e também de um ponto de vista da forma. A sociabilidade dá a universalidade dos julgamentos éticos, e está por trás do dito popular de que a voz de todos é a voz universal” (Mead, 1950: 379).

Kant acredita que só se podia universalizar a forma. Mead acrescenta que também se pode universalizar o fim. Esta possibilidade Mead explica com um movimento sutil, que vai estabelecer uma relação, antes impensada, entre o móvel da conduta humana e o fim a que se dirige. Segundo Mead, tanto Kant quanto os utilitaristas colocam a sociedade como um fim, mas em nenhum dos casos ela aparece como um objeto do desejo dos indivíduos. Assim, tanto quanto o hedonismo, também kantismo e utilitarismo "assumem que nossas inclinações [só] estão voltadas para nossos próprios estados subjetivos".

Mead subverte esse raciocínio. Ele observa que "se se deseja o próprio objeto, deseja-se aquilo a que pode ser dado uma forma universal; [mas, nesse caso,] se se deseja um tal objeto, o móvel ele próprio pode ser tão moral quanto o fim. A ruptura que o ato põe entre o móvel e o fim pretendido desaparece" (idem, 382). Se, portanto, o hedonismo reconhece o prazer como único móvel da conduta humana, Mead, no seu lugar, coloca o impulso que tem no fim sua razão de ser. Se isso é assim, os impulsos, que para Kant são ruins e para os utilitaristas são neutros, podem passar a ser julgados justamente pelo fim a que se dirigem. Mead pretende, com esse movimento, resolver o impasse da ética kantiana: os fins são bons, e

4 Como sempre, diante de qualquer aporia da filosofia kantiana, Hegel e Nietzsche tomam caminhos simetricamente opostos. Nietzsche pensa encontrar a solução na própria aporia, partindo para um relativismo axiológico que influenciou decisivamente Max Weber. Com isso, Nietzsche, de quebra, rejeita o modo de pensar essencialmente a-histórico dos utilitaristas, acrescentando ainda: "do pathos da distância [do que é inferior e plebeu] é que [os nobres] tomaram para si o direito de criar valores, de cunhar nomes de valores: que thes importava a utilidade!" (Para a Genealogia da Moral, \#2). Hegel, por outro lado, procura resolver a aporia com a introdução do conceito de eticidade, cuja mais alta manifestação é o Estado, o Deus realizado que põe o direito. 
conseqüentemente os impulsos que eles reforçam, caso levem a uma realização do si mesmo (self) como um ser social.

"Na validez das normais morais - observa Habermas - fica implicitamente conjurado o perigo que a depreciação da sociedade representa igualmente para todos os membros de um coletivo; o perigo da anomia, da desagregação da identidade do grupo, da desintegração de um plexo de vida social que é comum a todos os membros do grupo" (Habermas, 1985: 134). Contudo, “à diferença de (...) Kant e [d]os utilitaristas, [que] opera[m] com as categorias da filosofia da consciência, Mead concebe o processo de formação de um consenso normativo e de solução dos conflitos de valores a ele inerentes como o resultado da ação comunicativa de agentes que, ao interagirem, reconstroem a sociedade a que pertencem e, eventualmente, conduzem o grupo a novos padrões de moralidade." Não há como, nesse contexto, decidir privadamente sobre o pretenso interesse geral que uma determinada norma possa representar. Isso só é possível no âmbito da interação social em que cada indivíduo se posiciona criticamente em relação à tradição na qual se encontra desde sempre, renovando, dessa forma, aquele pano de fundo ético que torna a vida humana em sociedade possível. O princípio monológico da ética kantiana tem que dar lugar ao procedimento dialógico que a ética de Mead contempla.

Habermas, como se vê, no caminho que leva à fundamentação de uma ética do discurso, reaproxima-se criticamente, tanto quanto Mead, do formalismo da ética kantiana, acentuando, entretanto, contra Kant, seu caráter procedimental e intersubjetivo. Porém, Habermas - ao contrário de Apel (que caminha nessa mesma direção) - faz ver que o knock down definitivo nos céticos da moral só pode ser desferido pelos cognitivistas com a recuperação do conceito hegeliano de eticidade que, contudo, não se confunde, como em Hegel, com o Estado - reduzido, no modelo habermasiano, a um subsistema complementar à empresa capitalista, envolvido em tarefas de reprodução material da sociedade -, mas como um mundo da vida simbolicamente reproduzido pela ação comunicativa. ${ }^{5}$

5 Cf. "Notas Programáticas para a Fundamentação de uma Ética do Discurso", in Habermas, 1989: 61/141. A questão que surge é a de saber até que ponto a ética do discurso, que não mobiliza conceitos como o de divisão do trabalho ou classes sociais, a não ser pela mediação de uma categoria socialmente pouco elucidativa como a de distúrbios sistêmicos, pode ainda ser considerada legatária da tradição do materialismo histórico. Como Apel sublinhou, a origem da ética do discurso remonta a Peirce, que percebeu que a lógica da ciência moderna pressupõe uma lógica normativa da ciência, ou seja, uma ética. A ética do discurso é a ética de uma determinada "comunidade ideal", qual seja, a moderna camada social de indivíduos que dedicam suas vidas às atividades de criação e inovação. Camada social que, pela transformação da ciência em fator de produção, foi alçada à condição de classe social. A ética do 
Não obstante o enorme passo à frente que representa a teoria moral meadiana, Habermas objeta-lhe dois aspectos. 1) "Mead, segundo ele, permanece atento aos traços formais da evolução moderna da moral e do direito e aos traços formais do individualismo no âmbito do desenvolvimento da personalidade; mas passa por alto o reverso desse formalismo e não parece preocupar-lhe o preço que em moeda de eticidade concreta há de pagar a razão comunicativa por essa sua vitória" (idem: 155). Habermas refere-se ao processo de abstração e de perda de aura que experimentam os valores, convertidos em elementos manipuláveis e estereotipados. 2) Além do excessivo formalismo, Habermas aponta o viés idealista da teoria da sociedade de Mead: "a reprodução material da sociedade, o asseguramento de sua existência física, tanto frente ao exterior quanto ao interior, ficam apagados da imagem de uma sociedade entendida exclusivamente como um mundo da vida comunicativamente estruturado" (idem: 159).

Habermas procura sanar essas deficiências, entendendo a sociedade simultaneamente como um mundo da vida simbolicamente reproduzido e como um sistema, dele diferenciado, responsável pela sua reprodução material. Daí que, para ele, nesse ponto específico, a abordagem de Durkheim, complementada pela de Parsons, mostra-se superior. Apesar das deficiências da sociologia durkheimiana, na opinião de Habermas, ainda fortemente presa à filosofia da consciência, ela permite que se coloque em perspectiva tanto a diferenciação sistêmica quanto as formas de integração social, distinguindo-se os mecanismos de ação que asseguram um consenso normativamente alcançado dos mecanismos nãonormativos que funcionalmente estabilizam plexos de ação para além das consciências dos atores. Integração social e integração sistêmica correspondem, dessa maneira, aos dois elementos que compõem a sociedade: mundo da vida e sistema, respectivamente.

FERNANDO HADDAD é professor do Departamento de Ciência Política da USP.

discurso nada mais é do que a ética "universalista" dessa classe particular. Como força material que é, não pode ser desprezada pelo pensamento crítico, mas a extrapolação indevida do seu alcance revela que mesmo num mundo cínico ainda há espaço para a ideologia. 


\section{REFERÊNCIAS BIBLIOGRÁFICAS}

HABERMAS, J.(1985). Teoria de la acción comunicativa, vol. II, Taurus, Madrid. (1989). Consciência Moral e Agir Comunicativo, Tempo Universitário, Rio de Janeiro.

(1976). Para a reconstrução do materialismo histórico, Brasiliense, São Paulo. (1990). O discurso filosófico da modernidade, Dom Quixote, Lisboa. PEIRCE, C. S. (1931-1935). Collected Papers. Ed. C. Hartshorne e P. Weiss, Cambridge (Mass.).

KANT, I. (1781; 1987). Crítica da Razão Pura, Abril Cultural, São Paulo.

MEAD, G. H.(1950). Mind, Self and Society, The University of Chicago Press, Chicago.

APEL, K. O.(1985). Transformación de la filosofía, tomo II, Taurus, Madrid.

NIETZSCHE, F. (1987). Obras Incompletas, Abril Cultural, São Paulo. 


\section{RESUMOS/ABSTRACTS}

\section{DIALÉTICA POSITIVA: DE MEAD A HABERMAS}

FERNANDO HADDAD

$\mathrm{O}$ autor discute a importância da psicologia social de G. H. Mead para o pensamento social de Habermas. De especial interesse para o filósofo alemão é a confluência, em Mead, de duas linhas de reflexão do pragmatismo norte-americano - a filosofia analítica da linguagem e a teoria psicológica do comportamento - na crítica à filosofia da consciência. Apesar de denominar sua teoria "behaviorismo social", Mead se afasta das teorias do comportamento clássicas, ao enfatizar a experiência interna do indivíduo, e fazê-lo tendo como ponto de partida o "todo social". O artigo expõe, então, como a teoria da razão comunicativa pretende incorporar e, ao mesmo tempo, ultrapassar essa abordagem.

Palavras-chave: Teoria da ação comunicativa; psicologia social e pragmatismo; G. H. Mead.

\section{POSITIVE DIALECTIC: FROM MEAD TO HABERMAS}

The author discusses the significance of G. H. Mead's social psychology to Habermas's social thought. Two streams of the American pragmatism - the analytic philosophy of language and the behaviorist psychological theory - are united in Mead to criticize the philosophy of conscience. In spite of naming its theory as "social behaviorism", Mead breaks with classical behaviorism in so far as he emphasizes the individual's internal experience and presupposes the "social whole" in it. Finally, the article shows how the theory of communicative action claims to incorporate and, at the same time, to overcome that approach.

Keywords: Theory of communicative action; social psychology and pragmatism; G. H. Mead. 